DOI: 10.35784/IAPGOS.45

\title{
APPLICATION OF THE LENNARD-JONES POTENTIAL IN MODELLING ROBOT MOTION
}

\author{
Piotr Wójcicki, Tomasz Zientarski \\ Lublin University of Technology, Institute of Computer Science, Lublin, Poland
}

Abstract. The article proposes a method of controlling the movement of a group of robots with a model used to describe the interatomic interactions. Molecular dynamics simulations were carried out in a system consisting of a moving groups of robots and fixed obstacles. Both the obstacles and the group of robots consisted of uniform spherical objects. Interactions between the objects are described using the Lennard-Jones potential. During the simulation, an ordered group of robots was released at a constant initial velocity towards the obstacles. The objects' mutual behaviour was modelled only by changing the value of the interaction strength of the potential. The computer simulations showed that it is possible to find the optimal value of the potential impact parameters that enable the implementation of the assumed robotic behaviour scenarios. Three possible variants of behaviour were obtained: stopping, dispersing and avoiding an obstacle by a group of robots.

Keywords: swarm, Lennard-Jones potential, molecular dynamics simulation

\section{ZASTOSOWANIE POTENCJALU LENNARD-JONESA DO MODELOWANIA RUCHU ROBOTÓW}

Streszczenie. $W$ artykule zaproponowano metodę kontrolowania ruchu grupy robotów za pomoca modelu stosowanego do opisu oddziatywań międzyatomowych. Przeprowadzono symulacje metoda dynamiki molekularnej w uktadzie sktadajacym sie z ruchomych grup robotów oraz nieruchomych przeszkód. Zarówno przeszkody, jak i roboty składaty się z jednolitych sferycznych obiektów. Oddziaływania między obiektami opisano za pomoca potencjału Lennard-Jonesa. Podczas symulacji, poczatkowo uporządkowana grupa robotów poruszała się ze stała prędkościa w kierunku przeszkód. Wzajemne zachowanie obiektów modelowano tylko poprzez zmiane wartości parametrów potencjału oddziaływań. Symulacje komputerowe wykazały, że możliwe jest znalezienie optymalnych wartości parametrów oddziatywania, które umożliwiaja uzyskanie pożądanego zachowania robotów. W trakcie symulacji uzyskano trzy możliwe warianty zachowania: zatrzymywanie, rozpraszanie i omijanie przeszkód przez grupe robotów.

Słowa kluczowe: rój, potencjał Lennard-Jones, symulacja metodą dynamiki molekularnej

\section{Introduction}

Controlling multiple robots while maintaining a focused formation has been a major challenge for scientists for many years. The main inspiration for these applications is the observation of animals occurring in the natural environment in large groups $[3,14]$. Ants, bees, birds and fish are examples of how simple individuals can succeed when working in groups. The interest in social animals stems from the fact that they show some kind of group intelligence [3]. Nature provides many examples of groups of animals in which there is a phenomenon described as group intelligence. As a result, a group is able to perform complex tasks that individual individuals are unable to perform. Complex behaviour is the result of the combined efforts of individuals with extremely limited intelligence (resources). These complex, collective behaviours are derived from a small set of simple behavioural rules using only low-level interactions between individuals and the environment. The field dealing with these issues is known as swarm intelligence [2, 4, 14]. It concerns solving optimisation problems in the traditional mathematical approach and proposes a new computational paradigm: the calculation of the hive [2,14], in which there is no concept of central intelligence controlling the group. However, there are local interactions between individuals leading to the appearance of complex behaviours absent in the case of single objects $[4,10$, 14]. Many algorithms used to control single robots or groups of robots are based on the behaviour of groups of animals. The algorithm presented in [14] is inspired by the natural behaviour of bats using echolocation to move around, avoid obstacles and detect crevices in the dark. Maintaining a formation centred around a point or curve is also a behaviour that occurs in groups of animals. For example, ants move one after the other to form a chain - new units can only join at the end of the chain. Works [7, 8] show examples of how to obtain such a formation. Another example of inspiration for animal behaviour is study [5], in which the authors present a developed algorithm of communication in a group of robots based on ants communicating by means of pheromones.

An alternative to control inspired by biology and behaviour of animals in the natural environment are physical phenomena. In the real world, objects interact with each other. To describe these interactions, various equations are used with greater or lesser effect. One of the simplest is the Lennard-Jones equation proposed in 1924 [6]. It was used for the first time in computer simulations to describe the behaviour of so-called rigid spheres in 1957 [1]. Since then it has attracted continuous interest and has been applied in various fields of science. It was also used to describe the behaviour of a group of robots [9-12,15]. In paper [11] it was proposed to describe the motion of a group of robots based on the behaviour of particles in a liquid, partially using the LennardJones potential. Many papers describe the use of the potential for group behaviour and self-organisation [7-10,12].

The research was undertaken to better understand the mechanisms used to self-organise robotic groups inspired by physical phenomena. For this purpose, the molecular dynamics method was used to describe the motion of robots in $2 \mathrm{D}$ space and the interactions in the system were described by the LennardJones potential. The work consists of four parts: Introduction, Model, Results and Conclusions.

\section{Model}

Two-dimensional molecular dynamics simulations are carried out to study the behaviour of a group of robots. The simulation model is shown in Figure 1. It consists of several stationary obstacles and a moving group of robots. Both robots and obstacles are composed of spherical elements. To avoid "escape" of robots from the simulated area, system boundaries have been introduced.

The interactions between the objects in the system are described using the Lennard-Jones (LJ) potential (see Figure 2). It shows that depending on the selected parameters $\sigma$ and $\varepsilon$ and the mutual distance $r$, objects can repel or attract other objects. It was assumed that both robots and obstacles are unified and the interactions between them are assumed to be pairwise additive and the pair potential is represented by a truncated $(12,6)$ LennardJones potential:

$$
U(r)=\left\{\begin{array}{lr}
4 \varepsilon\left[\left(\frac{\sigma}{r}\right)^{12}-\left(\frac{\sigma}{r}\right)^{6}\right], & r \leq r_{\max } \\
0 \quad, r>r_{\max }
\end{array}\right.
$$

where $r$ is the distance between objects, $\varepsilon$ is the strength of the interactions, and $r_{\max }$ is the cut-off distance, equal to about $10 \sigma$ for both types of interactions. 


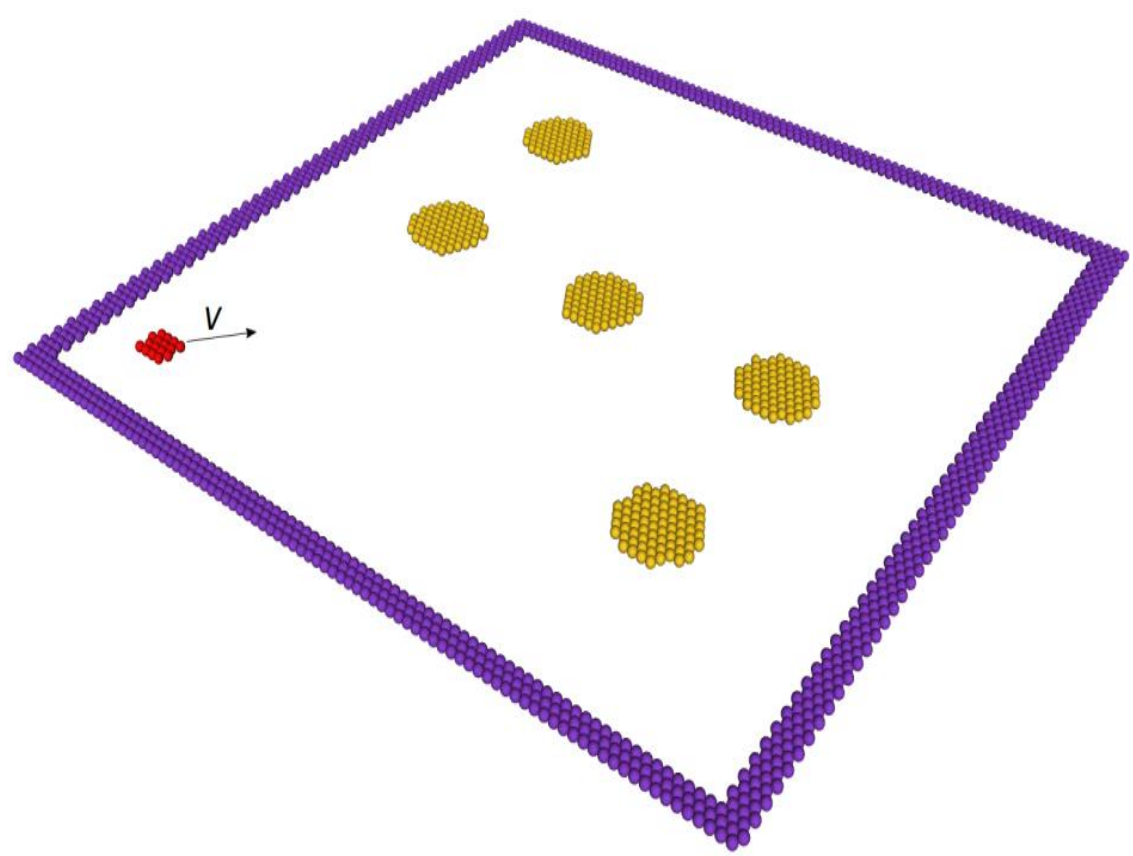

Fig. 1. Model of the simulation system. The obstacles are marked in yellow, the system border in purple and the robot group in red

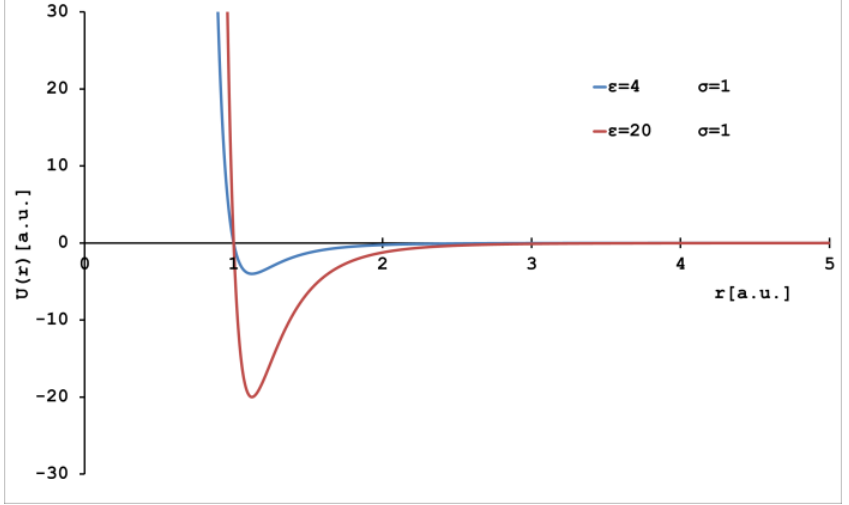

Fig. 2. Lennard-Jones potential for different values of the parameter $\varepsilon$

The resultant interaction (E) in the system is the sum of all interactions between all objects (2):

$$
\begin{gathered}
E(r)=\sum U_{s}(r)+\sum U_{o}(r)+\sum U_{w}(r)+ \\
\quad+\sum U_{s o}(r)+\sum U_{s w}(r)+\sum U_{o w}(r)
\end{gathered}
$$

where, $\mathrm{U}_{\mathrm{s}}, \mathrm{U}_{\mathrm{o}}, \mathrm{U}_{\mathrm{w}}$ are the interactions between robots, obstacle objects and boundary objects. These interactions are characterised by the corresponding values of the parameters $\sigma$, $\varepsilon$. In addition, there are mixed interactions between different types of components $\mathrm{U}_{\mathrm{so}}, \mathrm{U}_{\mathrm{sw}}$ and $\mathrm{U}_{\mathrm{ow}}$, where $\varepsilon_{\mathrm{so}}, \varepsilon_{\mathrm{sw}}, \varepsilon_{\mathrm{ow}}$ are the mixed interactions. We calculate them accordingly from the formula:

$$
\varepsilon_{i j}=\sqrt{\varepsilon_{i} \varepsilon_{j}}
$$

Throughout this paper, all the distances and lengths are expressed in the units of $\sigma$, and the energy parameter $\varepsilon$ of the potential (1) is the unit of energy. In addition, all objects have a unit weight. The trajectories of each object in the computational cell are obtained by integrating Newton's classical equation of motion. The integration is performed over finite time steps using a fifth-order predictor-corrector method. The time step used for solving Newton's equation of motion is $0.005 \mathrm{ps}$. The temperature during the simulation was kept fixed by periodical velocity rescaling and equal to $300 \mathrm{~K}$. During the simulation, a group of robots was assigned the velocity $\mathrm{V}=20 \mathrm{~m} / \mathrm{s}$ and then released towards obstacles. In order to speed up the calculations, the influence of the environment on the moving objects was omitted. The Ovito environment was used to visualise model [13].

\section{Results}

In order to investigate the influence of the parameters determining the force of the impact of the $\mathrm{LJ}$ potential on the behaviour of a group of robots, three research scenarios were proposed. It was assumed that each time a group of robots would be released towards obstacles at a constant speed V. The objects in the group can move relative to each other and have a spherical shape. The other objects in the system are motionless. It has been assumed that all component elements of objects will have the same size:

$$
\sigma=\sigma_{\mathrm{s}}=\sigma_{\mathrm{o}}=\sigma_{\mathrm{w}}=1.0
$$

and the only variable parameter will be $\varepsilon$. The competitiveness of interactions will be the decisive factor determining the behaviour of objects.

Table 1 summarises the LJ potential parameters used in the simulation to model the behaviour of a group of robots. They made it possible to observe three types of behaviour.

Table 1. Summary of simulation parameters

\begin{tabular}{|c|c|c|c|}
\hline \multirow{2}{*}{ Option } & \multicolumn{3}{|c|}{ Strength of interaction } \\
\cline { 2 - 4 } & $\varepsilon_{\mathrm{s}}$ & $\varepsilon_{\mathrm{o}}$ & $\varepsilon_{\mathrm{so}}$ \\
\hline I. Omission & 2.2400 & 0.1120 & 0.501 \\
\hline II. Stopping & 2.2400 & 0.0112 & 0.158 \\
\hline III. Dispersion & 0.1120 & 0.1120 & 0.112 \\
\hline
\end{tabular}

Figure 3 shows the results of the simulation for option I. It is observed that the group of robots initially moves along the planned trajectory. After sufficient approach to the obstacle, the group is internally reorganised and the obstacle is bypassed. The arrows show the successive stages of the movement of the group in relation to the obstacle. The influence of the obstacle is so big that the robots are not able to move too far away from the it. The trajectory of the flight is curved. The kinetic energy is so high that at the final stage of the movement the robots are separated from the obstacle.

It turns out that reducing the $\varepsilon_{0}$ parameter 10 times results in a behaviour change of the robot group. The calculated resultant value of $\varepsilon_{\mathrm{so}}$ is several times smaller than for option I and is $\varepsilon_{\mathrm{so}}=0.158$. For the same values of the $\varepsilon_{\mathrm{s}}$ parameter it results in an increase of the robot's willingness to adhere to the obstacle. Decreasing the value of $\varepsilon_{0}$ in effect results in an increase in the robots affinity to an obstacle. The observed behaviour is shown in Figure 4. 


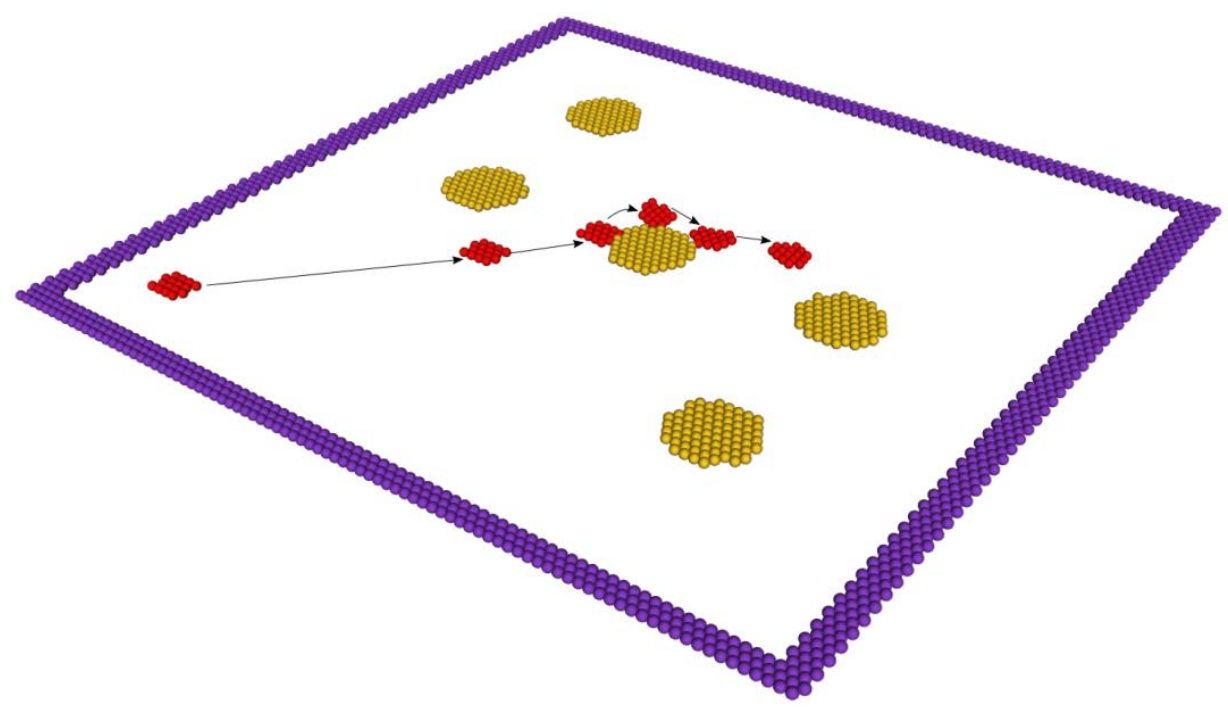

Fig. 3. Avoidance of an obstacle by a group of robots

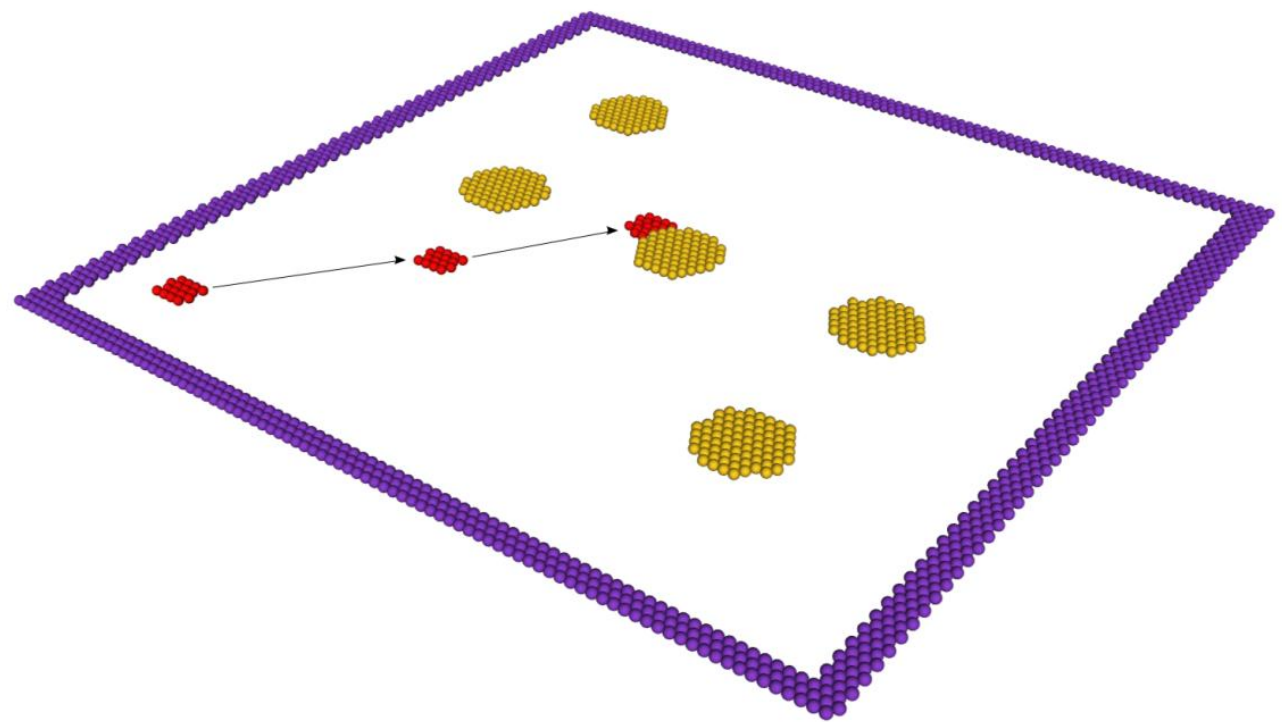

Fig. 4. Stopping a group of robots at an obstacle

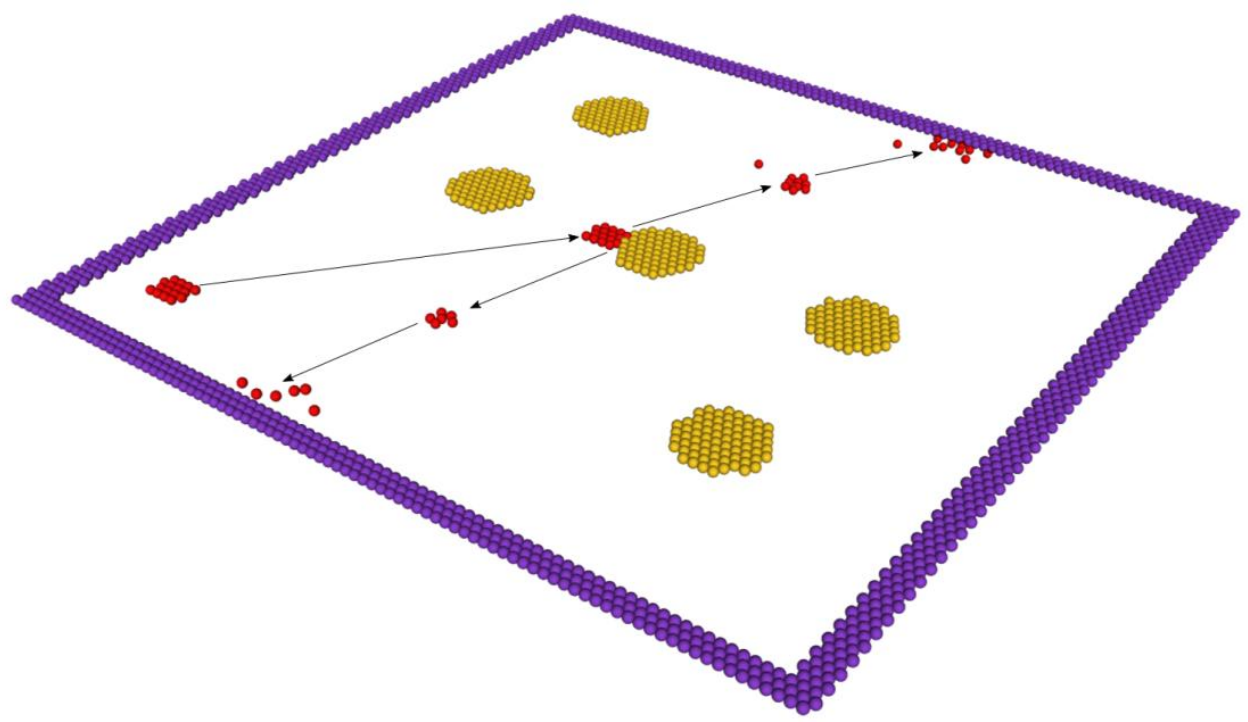

Fig. 5. Dispersal of the group on impact with an obstacle 
A completely different situation was observed when $\varepsilon_{\mathrm{s}}=\varepsilon_{\mathrm{o}}=\varepsilon_{\mathrm{so}}$. In this case, none of the interaction types is highlighted; all are equally weak. The group of robots after hitting an obstacle is dispersed. The kinetic energy delivered during the collision is sufficient to break up the group and scatter its elements. Additionally, a very small value of $\varepsilon_{\mathrm{s}}$ results in the inability to maintain the initial configuration of the robots and a dispersion of the group occurs. It has been noticed that the dispersion is multistage and one collision with an obstacle is not enough to completely break the formation. The situation described is shown in Figure 5.

Proper selection of parameters allows to keep the group in a focused configuration and bypass the obstacle. The presence of an obstacle on the trajectory of movement does not cause dispersion of group of robots. An incorrectly selected parameter of the strength of interaction $\varepsilon$ causes either the group to be attached to an obstacle or the formation to be broken up immediately. An additional factor influencing the behaviour of robot formation is also the speed of moving robots and the associated kinetic energy. The smoothness of movement will be maintained when the balance of forces is maintained in the system.

\section{Conclusion}

Simulations show that it is possible to use the Lennard-Jones potential to model the motion of a robot group. The selection of parameters has a key influence on the behaviour of objects. Three predicted types of behaviour were obtained: avoiding an obstacle, breaking up the group by an obstacle and avoiding a collision and stopping at an obstacle. Unfortunately, it was not possible to restore the formation of the group after it was broken up. The aim of future research will be to modify the type of potential or take into account other factors acting in the system, such as the resistance of the environment in which the objects move.

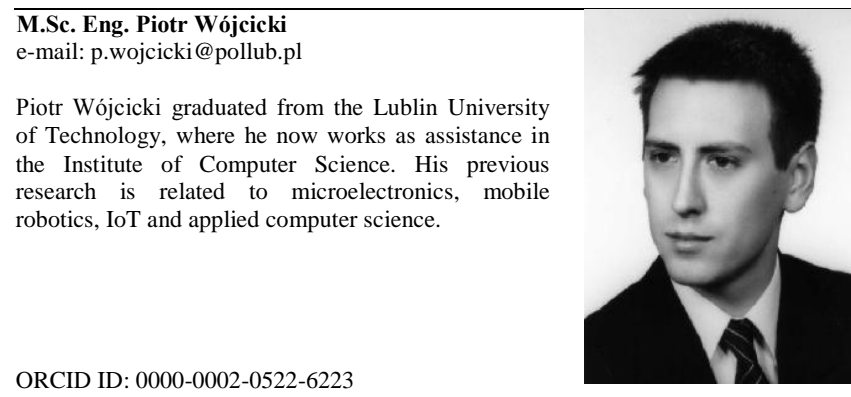

\section{References}

[1] Alder B. J., Wainwright T. E.: Phase Transition for a Hard Sphere System. Journal of Chemical Physics 27/1957, 1208-1209, [DOI: 10.1063/1.1743957].

[2] Blum C., Merkle D.: Swarm Intelligence: Introduction and Applications. Natural Computing Series. Springer 2008.

[3] Brambilla M., Ferrante E., Birattari M., Dorigo M.: Swarm robotics: a review from the swarm engineering perspective. Swarm Intelligence 7/2013, 1-41, [DOI: 10.1007/s11721-012-0075-2].

[4] Engelbretch A. P.: Computational Intelligence, John Wiley and Sons. England 2007.

[5] Farrelly C., Kell D. B., Knowles J.: Ant Colony Optimalization and Swarm Intelligence. Springer 2008

[6] Jones J. E.: On the Determination of Molecular Fields. Royal Society 106/1924, 463-477, [DOI: 10.1098/rspa.1924.0082].

[7] Maxim P. M., Spears W. M., Spears D. F.: Robotic Chain Formations. IFAC Proceedings Volumes 42/2009, 19-24.

[8] Nouyan S., Dorigo M.: Chain Based Path Formation in Swarms of Robots. ANTS Workshop 2006, 120-131, [DOI:10.1007/11839088_11].

[9] Olfati-Saberras R.: Flocking for multi-agent dynamic systems: algorithms and theory. IEEE Transactions on Automatic Control 51/2006, 401-420, [DOI: 10.1109/TAC.2005.864190]

[10] Pinciroli C., Birattari M., Tuci E., Dorigo M., et al.: Self-Organizing and Scalable Shape Formation for a Swarm of Pico Satellites. Proceedings of the 2008 NASA/ESA Conference on Adaptive Hardware and Systems (AHS 2008), 2008, 57-61, [DOI: 10.1109/AHS.2008.41].

[11] Shimizu M., Ishiguro A., Kawakatsu T., Masubuchi Y., Doi M.: Coherent Swarming from Local Interaction by Exploiting Molecular Dynamics and Stokesian Dynamics Methods. Proceedings 2003 IEEE/RSJ International Conference on Intelligent Robots and Systems (IROS 2003), 2003, 1614-1619, [DOI: 10.1109/IROS.2003.1248875]

[12] Son J. H., Ahn H. S., Cha J.: Lennard-Jones potential field-based swarm systems for aggregation and obstacle avoidance. International Conference on Control, Automation and Systems (ICCAS 2017), 2017, 1068-1072, [DOI: 10.23919/ICCAS.2017.8204374].

[13] Stukowski A.: Visualization and analysis of atomistic simulation data with OVITO - the Open Visualization Tool. Modelling and Simulation in Materials Science and Engineering 18/2009, 015012, [DOI: 10.1088/09650393/18/1/015012]

[14] Suárez P., Iglesias A., Gálvez A.: Make robots be bats: specializing robotic swarms to the Bat algorithm. Swarm and Evolutionary Computation 44/2019, 113-129, [DOI: 10.1016/j.swevo.2018.01.005].

[15] Sydney N., Paley D.A., Sofge, D.: Physics-inspired motion planning for information-theoretic target detection using multiple aerial robots. Autonomous Robots 41/2017, 231-241, [DOI: 10.1007/s10514-015-9542-0].

\begin{abstract}
D.Sc. Tomasz Zientarski
e-mail: t.zientarski@pollub.pl

Tomasz Zientarski is Head of the Department of Computer Science and Computer Modeling at the Lublin University of Technology. He is an associate professor there. His main scientific interests include computer simulation and modeling of physicochemical processes, industrial and mobile robotics, microelectronics, and wireless transmission.
\end{abstract}

ORCID ID: 0000-0002-1693-5316

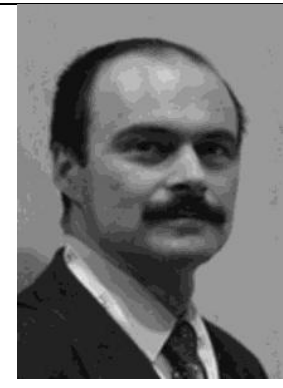

przyjęto do druku/accepted: 06.12.2019 